\title{
Leszek Ziora
}

Czestochowa University of Technology

e-mail: leszek.ziora@wz.pcz.pl

ORCID: 0000-0001-9253-3952

\section{CLOUD COMPUTING SOLUTIONS IN THE MANAGEMENT OF A CONTEMPORARY BUSINESS ORGANIZATION. THE VENDOR AND USER PERSPECTIVE}

\section{ROZWIĄZANIA CLOUD COMPUTING \\ W ZARZĄDZANIU WSPÓLCZESNĄ ORGANIZACJĄ \\ BIZNESOWĄ. PERSPEKTYWA DOSTAWCY \\ I UŻYTKOWNIKA}

DOI: 10.15611/ie.2018.4.13

JEL Classification: O3

Summary: The aim of the paper is to present the current state of cloud computing solutions application in the management of a contemporary business organization. The author outlined such theoretical aspects of cloud computing solutions as its key concept and architecture, and the benefits resulting from its implementation in contemporary companies and enterprises. The article presents the vendor perspective of cloud computing services utilization in business organizations prepared on the basis of case studies, practical examples and an international research review. The research presenting the user perspective on cloud computing usage was based on the opinions of 100 respondents of cloud computing services and indicated the pros and cons resulting from the implementation and application of this solution which allowed to indicate not only its benefits but also its limitations.

Keywords: cloud computing, software as a service, decision making support, Management Information Systems.

Streszczenie: Celem artykułu jest prezentacja aktualnego stanu zastosowań rozwiązań cloud computing w zarządzaniu organizacją biznesową. W tekście nakreślono teoretyczne aspekty funkcjonowania rozwiązania chmury obliczeniowej, przedstawiono jej koncepcję i architekturę, a także korzyści wynikające z jej wdrożenia we współczesnych przedsiębiorstwach. Artykuł przedstawia dwie perspektywy wykorzystania rozwiązania przetwarzania w chmurze: po stronie dostawcy - perspektywę zastosowań przetwarzania w chmurze przedstawiono na podstawie studium przypadków, przeglądu przykładów praktycznych, jak również zagranicznych badań, oraz perspektywę zastosowań tego rozwiązania po stronie użytkownika usług funkcjonującyh w chmurze obliczeniowej. Opracowanie powstało na podstawie ba- 
dań ankietowych przeprowadzonych w roku 2018 wśród 100 respondentów, co pozwoliło na wskazanie korzyści i ograniczeń wynikających z wykorzystania omawianego rozwiązania.

Słowa kluczowe: chmura obliczeniowa, oprogramowanie dostępne jako usługa, wspieranie procesu podejmowania decyzji, systemy informacyjne zarządzania.

\section{Introduction}

Cloud computing solutions are widely implemented in the practice of contemporary business organization management. The advantages of its implementation and application prevail over the disadvantages. This solution is an indispensable part of the Internet of Things concept as well as of the fog computing idea, and what is more it plays an essential role as far as its application in widely understood business analytics is concerned. Business analytics solutions in the cloud, such as Business Intelligence as a service, help to improve the quality of decision making, allow for the acceleration of the decision-making process and conducting real time business analyses. All this contributes to the improvement of the functionality of a contemporary business organization and may lead to the increase of competitive advantage, as well as the business value of the particular business organization. It is also worth noticing the fact underlined in the CompTIA report on 2018 trends in cloud computing that "cloud computing is a critical part of today's IT operations" [CompTIA 2018]. Pazowski and Pastuszak state that "business practice shows that companies which are capable of adapting to changing conditions in a short time, will always be in a better position than its competitors" [Pazowski, Pastuszak 2013]. The global use of computers and mobile devices which has increased nowadays and triggered business to expand into different global areas and this requires efficient use of resources toward the operational excellence which is possible thanks to the application of cloud solutions [Senyo et al. 2018].

\section{The characteristics of cloud computing solutions}

The paper is based on the widely accepted definition of cloud computing provided by NIST (the National Institute of Standards and Technology) where "cloud computing is a model for enabling ubiquitous, convenient, on-demand network access to a shared pool of configurable computing resources (e.g. networks, servers, storage, applications and services) that can be rapidly provisioned and released with minimal management effort or service provider interaction" [NIST... 2011]. The literature of the subject defines four main types of cloud storage: personal cloud where data of the individual user is stored, public cloud where enterprise data is stored outside a particular company in the infrastructure of the cloud service provider, private cloud where the data is stored by the cloud computing service 
provider in the data center of a particular company, and hybrid cloud which is the interconnection of a public and private cloud and in this solution, e.g. critical data for the functionality of a given enterprise or organization, is stored in a private cloud and the rest of the data in the public one.

Cloud computing may constitute an alternative for organizations which do not plan to invest in on-premise resources [Branco et al. 2017]. Q. Zhang et al. indicate the main benefits resulting from the application of cloud computing in the business organization as: lowering operating cost by the dynamic allocation of resources, the usage of a pay-as-you-go pricing model allowing paying for usage of particular resources, high scalability allowing for the expansion of offered services to larger scales, easy access to cloud services by different devices e.g. standalone computers, laptops or mobile devices possessing access to the Internet network, reduction of business risk and maintenance expenses where the cloud provider is responsible for ensuring the appropriate quality of its infrastructure [Zhang et al. 2010]. There can be distinguished such models of cloud services as: IaaS - Infrastructure as a Service connected to the on-demand provision of infrastructure resources, PaaS - Platform as a Service, which allows for offering e.g. operating systems in the cloud, and SaaS - Software as a Service providing software solutions for different areas of business activity e.g. e-commerce solutions.

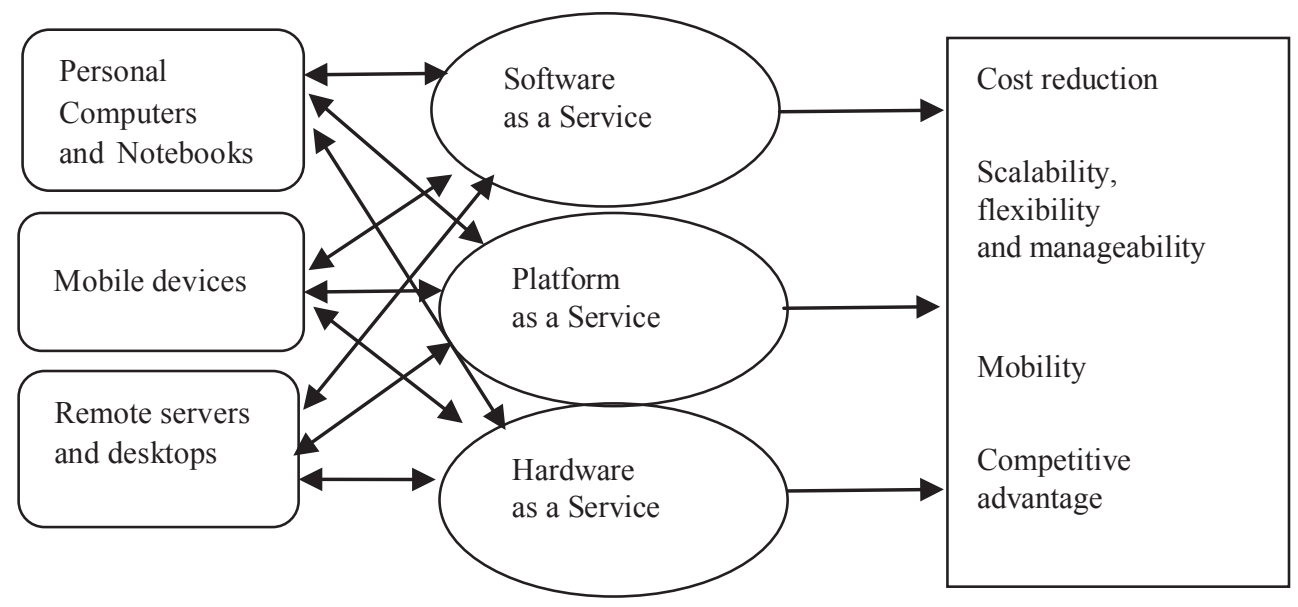

Fig. 1. General cloud computing environment for the management of business organization support Source: the author's own study.

IBM defines five crucial characteristics of cloud computing: an on-demand self-service where "users are able to provision cloud computing resources without requiring human interaction, broad network access supporting heterogeneous client platforms such as mobile devices and workstations, resource pooling by securely separating the resources on logical level, rapid elasticity where resources are 
provisioned and released on-demand and measured service where resource usage are monitored, measured, and reported" [Schouten 2014]. The example of cloud environment supporting the management of a contemporary business organization is presented in Figure 1.

The attributes of a cloud computing environment involve: availability, collaboration, elasticity, lower infrastructure costs, reliability, risk reduction and scalability [Dempsey, Kelliher 2018, p. 14]. The fundamentals of cloud computing are constituted by the combination of new and existing methods, techniques and IT tools such as [Dziembek 2016]: Service-Oriented Architecture (SOA) where services are adjusted to the consumers' needs and requirements, Utility Computing where the required resources are provided on demand taking into consideration e.g. computational power, the size of memory or the bandwidth, grid computing which consists of many interconnected computers in order to multiply and increase the computational power enabling the realization of many research projects, autonomic computing which automatically reacts to internal or external signals, and virtualization which allows for usage optimization of hardware and software. Cloud computing solutions have "the potential for better cost control, high quality services and flexible access to almost unlimited computing power - can affect the competitiveness of enterprises and help them react dynamically to changes in the environment" [Dziembek, Ziora 2018]. What is more, the financial benefits are connected with the reduction of operational and technological costs to improve cloud scalability and flexibility [Ziora 2012]. Venkatesh and Eastaff emphasize the fact that cloud computing "enables users to store their data in a remote storage location but data security is the major threat in cloud computing" and due to this issue a lot of business organizations hesitate in moving to the cloud [Venkatesh, Eastaff 2018]. The security threat is also confirmed by Q.K. Kadhim and others who claim that "there are five main issues associated with cloud computing implementation, namely mobility and cloud government application security issues, cloud security services and application, cloud security data, cloud network security issues and cloud security platform and infrastructure issues" [Kadhim et al. 2018]. Examples of selected commercial application of cloud computing solutions include Amazon Web Services (AWS), Microsoft Azure platform, Google App Engine and the IBM cloud.

Rimal and Lumb claim that cloud computing is significant for big data utilization "not only providing scalable infrastructures and on-demand high-performance computing and distributed storage to process and manage big data, but also providing a new business model, for example, big data as a service - a cloud service that allows users to collect, store, analyze, visualize, and manage their big data" [Antonopoulos, Gillam 2017]. Rountree and Castrillo mention the fact that "cloud providers make use of a concept called economies of scale, which is based on the fact that once the infrastructure for an application or service is built, adding capacity will only require incremental additions which means that the larger the environment, the greater the potential return on investment (ROI)" [Rountree, Castrillo 2014, pp. 12-13]. Taking 
into consideration the cloud economy, Babcock claims that "information that is of low value to one advisor gains value as it is aggregated with information from other advisors" [Babcock 2010, p. 171]. In the case of widely understood business analytics, "business intelligence and simulation systems in the cloud can provide all the companies in the network with transparency and visibility so they can all see the real-time status of network operations" [Hugos, Hulitzky 2011, p. 19].

\section{The vendor and user perspective on the basis of research}

As far as the cloud computing solutions from the vendor perspective is concerned it is worth mentioning the IDG research report entitled "2018 Cloud Computing Survey" carried out in order to measure trends among technology decision makers which indicted that "the average cloud budget rose from 1.62 million dollars in 2016 to 2.2 million in $2018,73 \%$ of those surveyed by IDG organizations have at least one application of its computing infrastructure in the cloud and $17 \%$ plan to do it within the next year, $38 \%$ of respondents claimed that IT departments feel pressure to migrate $100 \%$ to the cloud, organizations are utilizing a mix of cloud delivery models where currently the average environment is $53 \%$ non-cloud, $23 \%$ SaaS, $16 \%$ IaaS and $9 \% \mathrm{PaaS}, 42 \%$ of organizations are using multi cloud strategy" [Cloud Computing Survey 2018].

Another Business Insider report underlines the fact that cloud computing solutions are flexible and cost efficient. It states that the benefits resulting from the application of such solutions include "on-demand self-service, rapid elasticity, and broad network access". The report further states that the crucial factors affecting the implementation of cloud computing are security needs, demand predictability, existing infrastructure and maintenance capabilities [The Cloud Computing... 2017].

Another report prepared by Forbes in 2018 entitled "State of Enterprise Cloud Computing 2018" shows that "77\% of enterprises have at least one application or a part of their enterprise computing infrastructure in the cloud and $30 \%$ of all IT budgets are allocated to cloud computing in 2018".

Gartner confirms that cloud computing "impacts every aspect of IT and the business and it estimates that less than one-third of enterprises have a documented cloud strategy and in order to maximize the value of cloud investments, CIOs must develop a comprehensive cloud strategy for their organizations" [Advance Cloud Computing ... 2018]. The consultation cloud computing report shows that "cloud computing is central to the software continuum and edge/fog computing delivers low latency and near real time response time for demanding real-time applications" [Griffin 2016].

Cloud Computing Trends: 2018 State of the Cloud Survey which asked 997 IT professionals about their adoption of cloud infrastructure and related technologies indicated that "the preferred strategy among enterprises is the multi-cloud solution 
(present in $81 \%$ of enterprises), in comparison to previous years more enterprises utilize public cloud and on average five clouds are deployed" [Weins 2018].

As a supplement to the presented research reports it is worth presenting case studies related to the cloud computing utilization in contemporary business organizations. Atlassian "is an enterprise-software company that project managers, software developers, and content managers used to work more effectively in teams offering the JIRA software solution. This particular company needed to scale JIRA which started to support 15000 tickets every month as well as to ensure the high availability for this solution. In order to move into a more scalable environment, Atlassian created the JIRA Data Center and started using Amazon Web Services (AWS) together with Amazon Elastic File System (EFS). The advantages which resulted from its application was setup simplification and it can presently run an enterprise version of JIRA in the cloud, so in that way the company can put more effort into enhancing applications and rapidly scale applications. All this allowed to offer better and faster support of its customers [Atlassian...].

Another case study presenting the benefits resulting from cloud computing solution application is the example of the StubHub company which is a ticketing company providing tickets for more than 10 million live sports, music and theater events in more than 40 countries. As a cloud provider this company selected Google Cloud and Pivotal to support its ticketing platform when StubHub's legacy infrastructure was replaced. This step helped StubHub to significantly speed up the time of products and services arrival on the market, making it more competitive [StubHub... 2018].

Another case study showing the application of IBM Cloud is American Airlines which is moving critical applications together with "its customer-facing mobile app and check-in kiosks to IBM's cloud platform as a service (PaaS) and establishing a cloud-native architecture. This enabled delivery transformation, increased speed and productivity with increased scalability, performance and agility to improve business processes and customer experiences at the same time" [American Airlines 2017].

In the case of cloud computing user perspective, a research survey was conducted in 2018 of 100 individual users of cloud computing solutions using the CAWI solution - the survey form was placed on the Internet site and a link to the survey was sent to extramural and intramural students of Czestochowa University. The first question concerned what cloud computing service used: the respondents indicated that the most frequently used cloud services were e-mail platforms in $66.7 \%$ then the services allowing for file storage such as Dropbox, OneDrive, then in an almost equal way the platforms allowing for access to audio content such as Spotify, Tidal, Deezer and services providing video content such as Netflix, Amazon Prime Video, Showmax (including free of charge ones as YouTube and Vimeo) as well as social media services. The other popular cloud services included those allowing for the creation and editing of online documents such as text files, spreadsheets or presentations such as Google docs. Less popular among respondents were platforms connected 
with data security such as antiviruses in the cloud for standalone and mobile devices, applications supporting translation of documents, and the lowest popularity was linked with for the applications enabling video conferencing such as Clickmeeting, then the applications allowing for the creation of content, among which such Content Management Systems as WordPress, Joomla and Moodle were mentioned, as well as voice recognition services. The second question was devoted to the perceived advantages and disadvantages resulting from cloud computing utilization. As far as the advantages are concerned, the biggest number of respondents indicated the convenience and rapid access to the cloud services, free of charge access to many differentiated services, efficient use of memory and storage, good performance and flexibility, the possibility to use many applications and systems simultaneously, the possibility of using different devices from any location in the world having Internet access and without the need to use portable storage disks, flash drives or personal computer resources. As far as the disadvantages are concerned, most respondents indicated the possible occurrence of a security breach and threats resulting from unauthorized access to the cloud. A few respondents indicated that in the case of some services there is no possibility to download data on the users' local devices and some of the users are afraid of a data loss possibly due to different malfunctions e.g. lack of data redundancy which may occur, and the smallest number of respondents were concerned with possible data leakage and losing access to the account. And the third question was also devoted to the security issue and focused on the issue of whether in the respondents' opinion the cloud computing services offer sufficient security methods for the end user, where $60 \%$ of the respondents claimed that they provide a sufficient level of data and access to the system protection. The last question was connected to the level of satisfaction resulting from using cloud services and in this case $86 \%$ of respondents expressed their satisfaction ( $14 \%$ were not satisfied).

\section{Conclusions}

Cloud computing solutions, together with the more and more popular multi cloud strategy, are gaining in significance nowadays. Taking into consideration the user perspective these solutions bring a multitude of advantages such as convenient access to the user's data in any place, but on the other hand many users perceive the security threat as one of the biggest disadvantage. In modern contemporary organizations the implementation of cloud computing solutions is perceived as a paradigm shift towards the more flexible management of its resources. The multiple benefits also include the optimization and lowering of operating costs, its application flexibility and the improvement in collaboration among end users. 


\section{References}

2018 Trends in Cloud Computing, 2018, https://www.comptia.org/resources/cloud-computing-trends-research, retrieved: December.

Advance Cloud Computing Capabilities, https:/www.gartner.com/en/information-technology/insights/ cloud-strategy.

Antonopoulos N., Gillam L. (eds.), 2017, Cloud Computing, Computer Communications and Networks, Springer International Publishing AG.

Atlassian Case Study - Amazon AWS, https://aws.amazon.com/solutions/case-studies/atlassian/.

Babcock Ch., 2010, Management Strategies for the Cloud Revolution: How Cloud Computing Is Transforming Business and Why You Can't Afford to Be Left Behind, McGraw Hill, New York.

Bourne J., 2017, American Airlines moves consumer facing apps to the cloud - with IBM's help, https:// www.cloudcomputing-news.net/news/2017/jun/27/american-airlines-moves-consumer-facing-apps-cloud-ibms-help/.

Branco T., Sá-Soare F., Rivero A.L., 2017, Key Issues for the Successful Adoption of Cloud Computing, CENTERIS - International Conference on Enterprise Information Systems, Procedia Computer Science 121 (2017), pp. 115-122.

Cloud Computing Survey, 2018, IDG Research Report (2018), https://www.idg.com/tools-for-marketers/2018-cloud-computing-surve)y/, retrieved: November 2018.

CompTIA Survey, 2018, 2018 Trends in Cloud Computing, https://www.comptia.org/resources/cloudcomputing-trends-research.

Dempsey D., Kelliher F., 2018, Industry Trends in Cloud Computing. Alternative Business-to-Business Revenue Models, Palgrave Macmillan, Dublin.

Dziembek D., 2016, Cloud Computing - charakterystyka i obszary zastosowań w przedsiębiorstwach, [w:] Knosala R., Innowacje w zarządzaniu i inżynierii produkcji, Oficyna PTZP, Opole.

Dziembek D., Ziora L., 2018, The Management of IT Solutions Security Offered in Public Cloud Computing, Proceedings of ICoM 2018, 8th International Conference on Management "Leadership, Innovativeness and Entrepreneurship in a Sustainable Economy, Czestochowa, 7-8th June 2018, Wydawnictwo Wydziału Zarządzania Politechniki Częstochowskiej, Czestochowa.

Griffin D., 2016, Report on the Public Consultation on Cloud Computing Research and Innovation Challenges: Horizon 2020 Work Programme 2018-2020.

Horizon 2020 Work Programme 2018-2020, https://ec.europa.eu/digital-single-market/en/news/consultation-cloud-computing-research-innovation-challenges-wp-2018-2020.

Hugos M.H., Hulitzky D., 2011, Business in the Cloud: What Every Business Needs to Know about Cloud Computing, John Wiley \& Sons.

Jelonek D., Stępniak C. Ziora L., 2018, The Meaning of Big Data in the Support of Managerial Decisions in Contemporary Organizations: Review of Selected Research, Proceedings of 2018 Future of Information and Communication Conference (FICC 2018), Singapore.

Kadhim Q.K., Yusof R., Mahdi H.S., Al-Shami S.S.A., Selemat S.R., 2018, A Review Study on Cloud Computing Issues, 1st International Conference on Big Data and Cloud Computing (ICoBiC) 2017, IOP Confenence Series: Journal of Physics: Conf. Series 1018 (2018) 012006.

NIST Cloud Computing Definition, 2011, https://www.nist.gov/news-events/news/2011/10/final-version-nist-cloud-computing-definition-published.

Nowicki A., Ziora L., 2011, An application of Cloud Computing solutions in enterprises. Review of selected foreign practical applications, Prace Naukowe Uniwersytetu Ekonomicznego we Wroclawiu, nr 205, pp. 203-213.

Pazowski P., Pastuszak Z., 2013, Cloud Computing - A Case Study for the New Ideal of the IS/IT Implementation, Active Citizenship by Knowledge Management \& Innovation. Management, Knowledge and Learning International Conference, Zadar. 
Report on the Public Consultation on Cloud Computing Research, ec.europa.eu/newsroom/document. cfm?doc_id=42306.

Rountree D., Castrillo I., 2014, The Basics of Cloud Computing: Understanding the Fundamentals of Cloud Computing in Theory and Practice, Syngress, Elsevier, Waltham.

Schouten E., 2014, Cloud Computing Defined: Characteristics \& Service Levels, https://www.ibm. com/blogs/cloud-computing/2014/01/31/cloud-computing-defined-characteristics-service-levels/.

Senyo P.K., Addae E., Boateng R., 2018, Cloud computing research: A review of research themes, frameworks, methods and future research directions, International Journal of Information Management, vol. 38, issue 1, pp. 128-139.

StubHub case study. StubHub Selects Google Cloud and Pivotal for Digital Transformation Drive, 2018, https://www.cloudpro.co.uk/cloud-essentials/public-cloud/7473/stubhub-selects-google-cloud-and-pivotal-for-digital, 10 May.

The Cloud Computing Report (2017): An Introduction to Cloud Solutions and their Use Cases, 2017, https://www.businessinsider.com/the-cloud-computing-report-an-introduction-to-cloud-solutions-and-their-use-cases-2017-1?IR=T.

Venkatesh A., Eastaff M.S., 2018: A study of data storage security issues in cloud computing, International Journal of Scientific Research in Computer Science, Engineering and Information Technology 8 IJSRCSEIT, vol. 3, issue 1.

Weins K., 2018, Cloud Computing Trends: 2018 State of the Cloud Survey, https://www.rightscale.com/ blog/cloud-industry-insights/cloud-computing-trends-2018-state-cloud-survey.

Zhang Q., Cheng L., Boutaba R., 2010, Cloud computing: state-of-the-art and research challenges, J. Internet Serv. Appl., 1, pp. 7-18, https://link.springer.com/content/pdf/10.1007/s13174-0100007-6.pdf.

Ziora L., 2012, Rola technologii cloud computing w zarzadzaniu przedsiębiorstwem, Zeszyty Naukowe Ekonomiczne Problemy Usług Uniwersytet Szczeciński, nr 702, pp. 778-786. 